\title{
The Use of References in English News Published by Jakarta Post and New York Time Online Newspaper
}

\author{
Atik Muhimatun Asroriyah M. Pd, \\ English Education Department, University of Ma'arif Nahdlatul Ulama Kebumen \\ atik.ma25@gmail.com
}

\begin{abstract}
This study highlights the use of references in the element of cohesive devices in English news article of The Jakarta Post and New York Time written by Indonesian non-native and American native. The purpose of this study is to identify the similarities and differences in using personal references, demonstrative references and comparative reference. The method of this study is descriptive qalitative. The data were taken from online newspaper; The Jakarta Post and New York Times articles. There are 20 articles which are analyzed in this study, 10 articles from each online newspaper in any field of these newspaper. The data were analyzed use (Halliday and Hasan's : 1976) the theory of cohesion. The result of this study explained that the use of references in the New York Time articles higher than The Jakarta Post articles. The most dominant use the type of reference is personal reference both of the articles.
\end{abstract}

Keyword : cohesion, discourse analysis, reference, the Jakarta post article, new york time article

\section{INTRODUCTION}

Text is a sentence that connecting each other in logical way, text begin from topic and purpose to create/ built unity for a text (Halliday and Hasan, 1976, p.2) added a text is unit of the language in use, the word unit means not form but of meaning. It means that a text should have meaning in the form of sentence for the user of language or people that use language to communication. Text is a unified language including form and content, both written and oral that is delivered by a sender to the recipient to particular message. Text can be written and spoken, a spoken language related with communication that has been done by two persons such as conversation, dialogue, interview, speech, storytelling, while written language related with written form of communication include reading and writing. Both of reading and writing play important role in the written language, it can be manifested in the form of newspaper, book, and magazine. There are many of written language we often met in daily life, every morning we often see many seller of newspaper in the traffic light. But in this modern era, newspaper not only printed newspaper but in online newspaper. Online newspaper makes people easier in the read the newspaper and saving more paper.

Newspaper provide information around the world, there are many topic serve there such as politics, sport, economy, issue social, lifestyle, health, world, business, community, travel, video, opinion. Related with the function of newspaper is to give information, so the text in the article of newspaper should be readable and easy to understand.

Nowadays, there are many problem related with article in the newspaper such as the article have ambiguity meaning, not easy to be understand because of the word choice in arranging the sentences, the link in every sentence to another sentence not appropriate so the meaning will different, the writer from non-native language still use first language technique in the written English that makes their writing incoherent. 
According to ( Renkema 1993, p.35), State that there are seven criteria in the understanding a text. They are cohesion, coherence, intentionality, acceptability, in formativeness, situational, and in textually. It means that a text should be fulfilling one of these elements. This study is focus on cohesion. Cohesion is a semantics relation among elements of the text that makes a text meaningful ( Halliday and Hasan (1976, p. 8). The cohesion is the basic tools the quality of writing. ( Fadjrin ,2011, p. 3 ) added that cohesiveness can be built in the text through cohesion, example in the journalistic text. It can be seen that cohesion helps the reader understanding a text and also it makes easier to interpret the text. The use of cohesive devices is to link in each sentence in the text to create texture. The good arrangement of the text will create if the writers use the correct cohesive devices while the writer can avoid the incomprehensible in express their idea. Ahmed, 2010, p. 2). Pickering (1978) argue that cohesion is unit of discourse that has tie to connect each other in one or sentences. It means that there is a tie to link the word to another word that become a series of sentence that are coherent and cohesion. Halliday and Hasan (1976,p. 4) state that cohesion tie occurs when the sentence of the element in the text is stand as the tie that will connected each other. So, cohesion is linguistics tie or linguistics devices that has link to the unity of a discourse or text.

Cohesion is the important characteristic and principle of the quality of writing, they are connected each other, retrieval a word in one sentence, the basic of fundamental text into unity that become coherent and cohesion.

Cohesive devices divided into 2 types, there are Grammatical and Lexical Cohesion (Halliday and Hasan , 1976 ). Grammatical cohesion can be divided into main categories such as elipsis, conjunction, subtitution and reference. But in this study, researcher just focus on the element of reference. Reference is the information that have signal for retrieved from context of the text (Halliday and Hasan 1976, p.31) It can be said that reference is the word that represent something that have been told before.

Brown and Yule (1983, pp. 27-28), states that reference and discourse is the action that occurred in the text as one of the part or the participant of a writer. It explained what they are doing exactly. It means that it's not connect with other sentence or preposition. Mc Carthy (1991, p. 37) added that characterization of references is the information of signal and retrieval. The identity of the writer or the part of the text that being told has referential in the meaning, we can see before or after the word that become reference. Reference can be situational and contextual. Textual reference is reference in the text that related with the situational. Then contextual means describe the topic of the text. both situational and contextual divided into exophora or exophoric and endhopora. Exopohoric can be called as signals in the reference in the context of situational. While endophoric / endophora is cohesive tie they have contribution in the text that make the text connected each other.

(Suningsih, 2016, p.38) added the definition of reference is consist of aspect of discourse and the element that follow the sentence. Semantic unit built the relationship of substitution, and ellipsis between grammatical unit such as parts as clause it such as words, parts, clause, and sentence,. It means that reference can be detect by seeing the word before or after the occurrence. Reference can be divided into some aspects such as personal, demonstrative, and comparative reference. Personal reference related with the speech situation using noun or pronouns which is categorized into several types such as personal pronouns, possessive determiners, and possessive pronouns. The example of personal reference I, you, they, we, he, she, its, one, them, us, ours. Second type of 
reference is demonstrative reference that identify the reference by location through scale of proximity. These demonstrative divided into selective demonstratives and non-selective demonstratives. Example of demonstrative reference, the, this, those, that, these, here, now, there, then. And the last type is comparative reference, involve similarity or identity. Example, other, similarly, different, identical, equal, more, better, same, so, otherwise, less.

There were many research related with cohesive device that have been done by many researchers. Some of those studies are conducted by Gorjian (2017) analyzed cohesion in the use of references at articles that written by natives and non-natives. The writer analyzed the differences and similarities of the use cohesive, demonstrative, comparative amd personal reference. The writer collected 200 news articles national and international online newspapers and magazines from year 2011 to 2014 that include 100 articles from American native political news and 100 articles from Iranian non-native ones. The result of this study shows that American News got the higher of reference occurrence than Iranian non-natives.

Another study about cohesive has been conducted by Hamedi and Hessamy (2013), the researcher were compare and contrast the occurrence in the integrated and independent essays through the use of cohesion. 95 upper-intermediate Iranian EFL learner as the participant of this study. The result shows that the students prefer use anaphoric and cataphoric references, but substitution and ellipsis are rarely used. On the other hand, the researcher also found that the students better in the use of references and lexical cohesion in their integrated writing.

(Mirzapour and Ahmadi, 2011), also focus on cohesion tie in English and Persian Research Articles, the articles are 60 articles from journal but 30 articles from each language. The researcher took the data from any field of articles in each language. The element of lexical to be analyzed in this study. The result shows that both of the data the most dominant use are repetition, collocation, and synonymy. In English articles the dominant use are repetition and collocation, meanwhile for Persian articles are repetition ad synonymy.

In line with them, the researchers interested to investigated the use of cohesive devices as English references in two article of The Jakarta Post and New York time. As far as the writer knows, this study is different with the previous study because this study compare the Indonesian news and the new york time news it means the author is different.

\section{METHOD}

This study was conducted by using descriptive qualitative research. Descriptive research is a research that explained the data of the study through description in written and spoken forms in the language community ( Prayudha ,2016, p. 3). It means that the researcher explain the analysis through sentences. (Bogdan and Binklen, 1982, p.28) added that descrptive qualitative research is research that explain the phenomenon that occurs naturally.

The researcher used Simak catat technique by ( Sudaryanto, 2015) in collected the data . In getting the data, the researcher will do the following steps; first, the researcher collect the data from online newspaper. The writer took 20 articles from each newspaper online ( The Jakarta Post and New York Time). Second, the researcher read and categorizes the article of newspaper into the type of references. The last, identify,analyse and count the precentage the use of reference cohesion. 
In the analyzing the data, the researcher use the theory of Halliday and Hasan (1976) cohesion in English.The instrument of this study are the article from the newspaper and human instrument / the researchers itself as the tools to analyze the data.

\section{FINDINGS AND DISCUSSION}

The two articles of Jakarta Post and New York Time were analyzed concern with the frequency of occurrence of reference that divided into three categories such as personal, demonstrative, and comparative reference. The data explained in the following chart bellow.

\section{Chart I. Jakarta Post and New York Time using Reference}

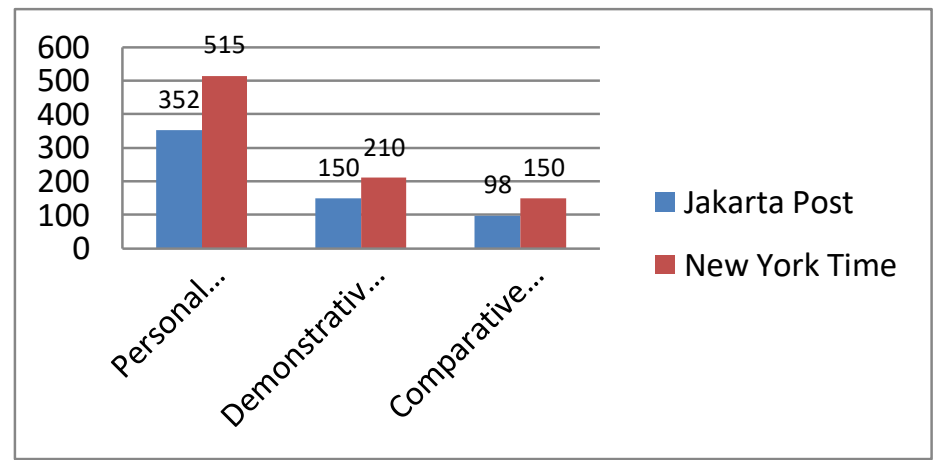

This chart is shows the type of reference in the use of cohesive reference in both article jakarta post and New York Time. This chart explain that personal reference is higher than other type of reference. The number of personal reference from Jakarta post was 352 equal to $40.6 \%$ and the now york time was 515 equal to $59.4 \%$, personal reference was the most commonly use in both of the newspaper, but the hightlighted in this study was from New York Time Article. Another type of reference was appear in these article, the number of the use demonstrative reference in Jakarta Post was 150 time equal to $40.5 \%$, while the new york time was 210 was $56.7 \%$. and the last from The number of comparative reference was 98 from Jakarta Post equal to $39.5 \%$, and new york time was 150 equal to $60.4 \%$.

The result of this study shows that there are three kinds of reference occurrs in the both of newspaper. The references were personal, demonstrative, and comparative. Reference is represent the participant in the text that written by writer, to know the information about the text we should know the participant/ the object that have told by the writer. The researcher found that personal reference were higher than other type of reference both of Jakata Post and New York Time.

\section{a. Personal Reference}

There are three kind of Personal reference such as pronoun, possessive adjective, and possessive pronouns. In the articles of The Jakarta Post, the writer found that personal pronoun is the most frequency used in the article such as I, me, they, we, us, he, him, she, her, they, them, it, one. It can be seen in the example of piece of the text "Along with intensive public education, mandatory vaccination must be seriously considered. Children afflicted with polio, for instance, may eventually question why adults failed them. They are unlikely to accept the answer that our leader respected their parents' freedom of choice, one that impaired them for life." 
In this example, there is word "them" which included of personal reference. The word " them "represent the word that has been mentioned before "Children afflicted", its called anaphoric. The word " their " also refer to the word " children afflicted" so its also called anaphoric. Anaphoric is relationship of the word that mentioned before in the text for their interpretation. ( Halliday \& Hasan, 1976 p.37)

In the article New York Time the possessive pronoun dominant occurs such as my, your, our, his, her, their, its, one's. The example below explained that the word "it's" refer to the word that has been mentioned before "Miami Beach", its called anaphoric. The word " Haiti " followed the word " my " it was representation the identity of the pronoun.

"But Miami Beach's recovery from Hurricane Irma. Which slammed into this low-lying resort city in September and turned the main thoroughfare of Collins Avenue into a water way, has occasioned its own round of reconstruction"

b. Demonstrative Reference

Another type of reference is demonstrative reference, this classes was found in The Jakarta Post articles. Demonstrative reference is refer to the speaker identities by locating it based on the distance of the text. In the Jakarta Post articles, the writer found that the writer often use this, those, these, the, meanwhile the word here, there, then are rarely use in these article, moreover it just occurs one or two word. Here the example of it. The word " this " refer to current periods of time. The word "those" refer to the "three more free vaccines" that has been mention before.

" $\underline{T h i s}$ year,Health Minister Nila Moeloek announced that three more free vaccines would be provided on top of those for DPT, tuberculosis and measles."

"Neurons develop from neural stem sells in the hippocampus, a structure vital for learning ad memory. Under chronic stress, these stem cell undergo an alternate differentiation pathway, forming oligodenrocytes, which coat existing neutrons with an insulting material known as mylin"

Beside that in the Artcile of New York Time the researcher found the kind of demonstrative reference such as this, those, these, that, then, there, here, now, the, but the dominant use in these article are this, those, these, that, here, the. From the example below, the word " this " means that something is near from the speaker.

"This is a time for them to show up," she said. "Especially Schumer because he has a lot more leverage in the Senate to say, 'This is_on the top of my agenda, and I'm going to move my entire caucus to vote no on the spending bill if the Dream Act is not on there.' But we have not been able to get him to even acknowledge that or say that. So it's absolutely frustrating for a lot of us."

"Democrats are not willing to shut government down," Ms. Pelosi told reporters, while also saying, "We will not leave here without a DACA fix."

"Here's the third-biggest school system in the country that's dramatically outperforming not just the other big poor districts, but almost every district in the country, at scale," Mr. Reardon said

c. Comparative Reference 
The last type of references is Comparative reference, the writer found there is comparative reference in both articles, they are more, less, so, as, better, same, other, either, rather than. Comparative means identity or similarity.

In the article Jakarta postound that the comparative reference dominant use are less than, as, morethan, and some rarely use such as same, other. The example of Jakarta Post artice that consist of comapartive reference :

"Gay marriage, authorized on Tuesday by Austria's top court by 2019 at the latest, is now recognized in more than 20 countries, of which 16 are in Europe.

"Mexico's federal capital was the pioneer in Latin America, authorizing civil unions in 2007 and marriages in 2009 as well as adoption.

Transient insomnia - insomnia that lasts less than a month - may be the result of a temporary problem at work or an acute illness;

The word " more than "it is enumerative comparison reference that refer to numbered of countries that are organize gay marriage. The word " as" means comparative of quantity, with a numerative as comparative "well as adoption" is the reference. The word "less than" refer to enumerative comparative, it means that the people who get insomnia in one month.

Beside that, the writer found that comparative reference occure in the articles of Time New York such as other, as, same, better, more, else, similarly. The most dominant use in this article are other, more, most,as. See the example below :

"The same, it would seem, may be said of a related recommendation to create a subway development corporation,"

"The data, based on some 300 million elementary-school test scores across more than 11,000 school districts, tweaks conventional wisdom in many ways. Some urban and Southern districts are doing better than data typically suggests. Some wealthy ones don't look that effective."

"By comparison, children in the Milwaukee Public Schools test at similarly low rates in the third grade but advance more slowly, leaving them even further behind by the eighth grade."

If we understood what was causing that, in Chicago and other disadvantaged but highgrowth districts, that might help reduce educational inequality, he said.

Use the search box here or elsewhere on the page to see how your local school district compares with others in its county or nearby.

The word "same" it is involved of general comparative identity. I that context, it is related with recommendation to create a subway. The word "more than" it is enumerative comparative, the number of school in the district is 11.000 from or 300 million . the words " better ", it is particular of comparison which better in this context means the data better than the suggests. the word "similarly ". The word "similarly" its general comparison that means that "similar each other". The word " other ", its the comparative reference in the element of difference. It means that there are another country that faced the disadvantages. 


\section{CONCLUSION}

In conclusion, the researcher found that the articles of The Jakarta Post and New York Time has the highest occurrence and the lowest occurence of the cohesive devices through the gramatical cohesion in element reference. The cohesion is the basic tools the quality of writing. Cohesiveness can be built in the text through cohesion, example in the journalistic text. It can be seen that cohesion helps the reader understanding a text and also it makes easier to interpret the text. The use of cohesive devices is to link in each sentence in the text to create texture. The good arrangement of the text will create if the writers use the correct cohesive devices while the writer can avoid the incomprehensible in express their idea. There are type of reference, personal reference, demonstative reference, comparative reference. Reference is describe the signal that connect one sentence to another sentence.

Cohesion is the important characteristic and principle of the quality of writing, they are connected each other, retrieval a word in one sentence, the basic of fundamental text into unity that become coherent and cohesion.

The writer found that personal reference is dominant appears in the both of the articles, the other type of personal reference also dominant use in these articles is demonstrative reference and the last position for this even rarely use is comparative reference. The differences between article from The Jakarta Post and New York Time in the item of personal references are The Jakarta post they dominant use possesive pronoun(I, me, they, we, us, he, him, she, her, they, them, it, one), meanwhile the New York Time article use possessive pronoun and adjective pronoun ( I, my, your, our, his, her, their, its, one's). The occurrence demonstrative reference items was also prominent in these articles, but less than personal reference. The word of "the" is the dominant use as the demonstrative reference in both of these articles. And the last in the occurrence of comparative reference items was lowest than other reference, researcher found some compartive reference in both of articles. In The Jakarta Post article the word " other" is dominant use, while the word "same " is the dominant use in the New York Time Article.

Finally, it can be said that writer of New York Time and The Jakarta Post article have a good knowledge of reference, although the American article higher than Indonesian article. It may occurred because the writer is influenced by their first language and culture. Although the article of the New York Time is higher in the occurrence of the use references in those article.

\section{REFERENCES}

Aghdam and Hadidi.(2015).Cohesion and Coherence in Political Newspapers and Discussion Sections of Academic Articles. International Journal on Studies in English Language and Literature (IJSELL) Volume 3, Issue 3, March 2015, PP 11-22 ISSN 2347-3126 (Print) \& ISSN 2347-3134 (Online) www.arcjournals.org

Ahmed, A. (2010). Students' Problems with Cohesion and Coherence in EFL Essay Writing in Egypt: Different

Perspectives. Journal of Helwan Faculty of Education, Literacy Information and Computer Education Journal (LICEJ), Volume 1, Issue 4, December 2010.

Connor, U. (1984). A study of cohesion and coherence in English as a second language students' writing. Papers in Linguistics, 17, 301-316. 
Gurning, B and Jambak,Vany . _..Cohesive Devices Used in the Headline News ofTheJakartaPost.http://download.portalgaruda.org/article.php?article $=167562 \&$ val $=$ 3892\&title=COHESIVE\%20DEVICES\%20USED\%20IN\%20THE\%20HEADLINE $\%$ 20NEWS\%20OF\%20THE\%20JAKARTA\%20POST

Hadi .(2013).A Comparison of the Use of Cohesive Devices in EFL Learners' Performance on Independent vs. Integrated Writing Tasks. International journal of humanities and cultural studies issn 2356-5926

Hessamy and Hamedi.(2013). A Comparison of the Use of Cohesive Devices in EFL Learners Performance on Independent vs. Integrated Writing Tasks. www.scholink.org/ojs/index.php/selt Study in English Language Teaching Vol. 1, No. 1; February 2013

Neisi and Gorjian. (2017). A Comparative Study of Using References in English Political News Written by English Language Natives and Non-Natives. Journal of Applied.

McCarthy, M. (1991). Discourse analysis for language teachers. Cambridge: Cambridge.

Mirzapour and Ahmadi. (2011). Study on Lexical Cohesion in English and Persian Research Articles. Published by Canadian Center of Science and Education . English Language Teaching www.ccsenet.org/elt Vol. 4, No. 4; December 2011

Pickering, W. (1978). A framework for discourse analysis. Arlington: University of Texas.

Prayudha.(2016).The Cohesion and Coherence of the Editorials in The Jakarta Post. Journal of Ahmad Dahlan Journal of English Studies (ADJES) Vol. 3, Issue 2, September 2016.

Rahman, Zuhair .(2013). The Use of Cohesive Devices in Descriptive Writing by Omani Student-Teachers. Journal of SAGE Open October-December 2013: 1-10 The Author(s)2013DOI:10.1177/2158244013506715 sgo.sagepub.com

Renkema, Jan. (1993). Discourse Studies: An Introductory Textbook. Amsterdam: John Benjamins Publishing Company.

Sudaryanto.(2015). Metode dan Aneka Teknik Analisis Bahasa.Yogyakarta: Universitas Sanata Darma

Verikaite, D. (1999). Formal and functional characteristics of cohesive devices in the science research article in English. Doctorial Dissertation. Vilnius: Vilnius Pedagogical University. 